\title{
Creating my academic self and space: autoethnographic reflections on transcending barriers in higher education
}

\section{Ronicka Mudaly}

\begin{abstract}
This article focuses on my ethnographic self-reconstruction in order to explore my academic journey, by critically evaluating the influence of professional academic cultures on my teaching practice, with a view to understanding my professional identity. I make visible to the reader and myself my suppressed feelings, emotions and ambitions by analysing learning opportunities that facilitate my 'being' an academic. Drawing on theoretical frames from autoethnography, I engage in personal epistemological vigilance by directing my sociological gaze inwards. I retroactively and selectively draw on diary recordings of my own micro-ethnographies, and my teaching portfolio statement as the data sets. My entry into this slippery, treacherous space evokes feelings of vulnerability and hyper-visibility. It illuminates the struggle of being on the right-hand side of binaries such as disciplinary specialist/ interdisciplinary researcher, experienced/novice academic, and scholar/teacher. This work has implications for other academics who feel undervalued, over-extended and trapped in the labour of teaching.
\end{abstract}

\section{Why and how I tell my story}

In this narrative, I make a conscious effort to understand and make visible my professional experience including my suppressed feelings, emotions and ambitions as a woman academic. This exploration of my academic journey illuminates "educational challenges that have resonance beyond the self" (Pithouse, Mitchell and Webb, 2009, p.43) and creates an opportunity for crafting responses to these challenges. Delamont $(2007, \mathrm{p} .1)$ argues that "introspection is not an appropriate substitute for data collection" and cannot be used to drive our "disciplines forward". I contend that my account is not embedded in a solipsistic intention. Far from being an endeavour in selfobsession (Delamont, 2007), this sharing of my experiences is intended to have transferable implications for other academic identities. I look for cultural meanings of my lived experiences with others, and analyse these using supporting literature. 
I engage in this autoethnographic account using a subjective lens to gain and share new understandings of the interaction of my academic self with the higher education professional culture. Spry (2001, p.711) describes the autoethnographic researcher as the "epistemological and ontological nexus" of the research process. Autoethnography connects the knower to what is known, and to what is knowable, and thereby links the "personal to the cultural" (Ellis and Bochner, 2000, p.739). Based on the ontological assumption that cultural realities are perceived differently by people who emerge from the same cultural setting, the autoethnographer seeks to offer "narrative truth as pragmatic truth" and strives for "verisimilitude and truthfulness" instead of precision and truth (Ashley and Peterson, 2015, pp.226-227).

\section{Entering the world of academia}

After teaching secondary school Biology for 22 years, I enthusiastically entered the world of higher education. My achievements as a teacher had included my qualification with a doctoral degree in education, my appointments to the positions of Head of Department in Science and Mathematics education, provincial examiner, senior marker, cluster coordinator for Biology, and examiner for the National Science Olympiads, among other things. I was well-known and well-liked by subject advisors and my peers, and felt confident to take the vertiginous leap into the world of academia.

I resigned from the position as a school teacher on a Friday, and on the subsequent Monday, I began my work as a teacher in an academic institution in the Department of Science Teacher Education. I felt that I was given a blank page on which I could make my mark in higher education. Little did I realise that the "invisible ink of expectation" (Hayler, 2011, p.3) was very real. There was no academic who was appointed to nurture me into the teaching practices at this level. A module file was handed to me and I was requested to teach. I was allocated several undergraduate classes with large numbers of students, and this resonates with experiences of early career academics in other settings (see Fitzmaurice, 2013; McAlpine, 2014). The mentor who was assigned to me conducted a lecture visit once during each of three semesters, and wrote a report; this was the limit of mentorship. This lack of "systemic socialization" was also experienced by early career academics in 
Portnoi's study (2009, p.187). A small storage room which was located a distance away from offices occupied by staff was allocated to me. An old computer was given to me. I had neither a telephone nor access to a printer or photocopier. My 'office' was equipped with two large, old wooden tables and a small bookshelf. In a moment of intuitive perspicuity, I realised that I was literally and figuratively a 'peripheral professional'.

The teaching was exhausting. After the end of teaching, I remained on campus, adapted materials from the module files and generated new teaching materials. There was no joint enterprise in sight and no further sharing of skills and expertise. Three weeks after my appointment, I was called to a meeting and asked about my plans for research outputs. Having been overwhelmed by teaching responsibilities, I realised I had hardly given any thought to writing scientific papers. I was embarrassed and felt like an unworthy investment because I neglected to attend to that most critical part of being an academic, known as PUs (an unfortunate acronym!) or productivity units. Unlike early career academics in the study conducted by Fitzmaurice (2013), I was not acutely aware of the fiscal austerity which demanded performance in terms of research productivity units. The euphoria of being an academic rapidly atrophied as the reality that I was in an unfamiliar space, which was disordered, descended. This, however, represented a transcendental moment, a moment in which I resolved to create the opportunities to re-orientate in order to navigate the higher education terrain.

The first step was to make a conscious effort to understand my professional experience and to locate myself as the "epistemic subject" (Greene, 1971, p.3). By becoming fully attentive to my professional life, I would be enabled to perceive new things en route to what Phenix (cited in Greene, 1971, p.6), refers to as "self transcendence" which enables one to simultaneously be "agent and knower and at once to identify with what (one) comes to know". In order to chart the academic terrain, I needed to make landmarks visible which presented themselves as questions. How do I meet the requirements of the work of an academic, which included teaching, research and community engagement? What is the critical literature related to my scholarship of teaching? What informs my approaches to teaching and assessment? Which philosophies underpin my journey through the academic triad of the teaching, research and community engagement? Who are the philosophical giantesses and giants who influence my thinking? What is my research niche area? How does my academic work intersect with what Husu (2001, p.178) refers to as the "complexity of women's academic positions"? How can I become that 
academic whose contribution is not trebly negligible because she is black, a woman and in the junior echelons of the higher education hierarchy?

In "stepping back" I examine my "situated self" which is contingent on the socio-political and historical milieu (Pithouse, Mitchell and Webb, 2009, p.44). This personal exploration of "scholarship in and through teaching" (Loughran, 2004, p.7) is underpinned by theoretical constructs from "postmodern, feminist and post-colonial paradigms" (LaBoskey, 2004b, p.818). Instead of perpetuating the status quo, my retrospective introspection aims to "provoke, challenge and illuminate" (Bullough and Pinnegar, 2001, p.20). I position myself as, what LaBoskey (2004a) refers to, being both actor and spectator.

\section{Why autoethnography?}

Ellis, Adams and Bochner (2010) contend that researching thoughts, actions and emotions which are rooted in personal experience, raises the consciousness of readers to identity politics. They add that autoethnography can also remove the shroud of silence around personal decisions related to meeting institutional requirements. Maistry (2015) ventures beyond this veil of silence at a South African higher education institution by offering a candid account of how academics are coerced to comply with officially sanctioned performance requirements. He refers to the "dense surveillance network" (Maistry, 2015, p.30) to which academics are constantly subjected, and he provides a personal account of his position within that network which he refers to as the "power machinery" (p.31). His commitment to the "understanding of truth telling, or parrhesia" (Maistry, 2015, p.25), elucidates an institutional structure which relentlessly unleashes its disciplinary power.

The value of autoethnography in understanding identity politics of contemporary academics is evident in the works of several researchers. According to Archer (2008, p.387), academic identity development involves non-linear, disrupted processes of "unbecoming" young academics when they cannot contribute to the corporate demands of the university within the fixed time frame. The constant stress and pressure and the real threat of being "rendered illegitimate" erodes at new academics' sense of self (Archer, 2008, p.390). Archer's study (2008) reveals how self-doubt about their competence paradoxically resulted in novice academics' choice to engage in inauthentic, 
contrived behaviours and language, in order to be perceived as authentic academics, and a legitimate investment. Dison (2004), who researched students who were enrolled in a research capacity development workshop, found that young academics experienced race and gender prejudices. Researchers who were black and female were engaged mainly as field workers, because they were perceived to be familiar with black peoples' culture and language. However, once the data had been generated, it was to be handed to researchers who were perceived to be more competent to interpret and write - these were white, 'authentic' researchers. The effects of racialised and gendered asymmetries of power on becoming (and possibly unbecoming) an academic persist in post-apartheid South Africa (Dison, 2004; Maritz and Prinsloo, 2015).

\section{Autoethnography among teacher educators}

Hayler (2011, p.13) underscores the need to hear voices of teacher educators through "self-narrative ... lived experience with all its historical, social and cultural contexts ... it follows that experiences of teacher educators offer insight and illumination in this key area of education". Connelly and Clandinin (1990, p.4) assert that a crucial quality of narrative inquiry in education by storying and restorying one's life is the possibility of generating "stories of empowerment". This can be enhanced by applying the characteristics of autoethnography, as elucidated by Ellis, Adams and Bochner (2010). These include the production of thick descriptions of experience, both with oneself and with others; the use of methodological tools for reflexive inquiry; writing about critical moments or epiphanies which result in a significant direction in the trajectory of one's career; the consideration of how other people may have experienced similar critical moments; the accommodation of emotionality and subjectivity in research, the troubling of canonical ideas which underpin conventional research; and the different assumptions which people possess of the world which are based on social markers of difference, such as age, race, social class, gender and level of educational achievement. These characteristics inform the telling and interpretation of my story. 


\section{My story}

I play my hand and tell my story (Hayler, 2011), and in sharing this experience of making sense of my professional life, I hope to contribute to my and other academics' understanding of teacher education and teacher educators. I do not intend to negate the "poststructural, antifoundational arguments" (Denzin, 2006, p.421), which are becoming increasingly conspicuous in the social sciences research landscape. Therefore I will not embed my story in parochial philosophical paradigms. I am aware that "reductive analytic analysis and theorization" (Canagarajah, 2012, p.258) is considered by some researchers as being subaltern to the rich, descriptive stories which constitute evocative autoethnography. I cannot deny my emotional recall of forgotten motivations and suppressed feelings, experienced as a nascent academic. However, I weave the thread of professional identity as I story my interaction with different academic cultural communities. I am reminded that autoethnography as a methodology is simultaneously ethnographic, interpretive and autobiographical (Chang, 2008; Ellis, Adams and Bochner, 2010). Therefore, I consciously engage both emotionally and cognitively in order to give an account which is faithful to my experience.

My initial professional identity in higher education was a teacher of undergraduate students in the school of science education. I aspired to become more than this. One critical moment which fueled this aspiration came at the end of 2008, after my first eight months in academia. It involved a chance meeting with a senior management member. He was walking hurriedly up a staircase which I was descending. He offered a courteous greeting and while stepping, he said that he wanted to meet me and talk about publications. I said that I had published one article. He stopped climbing. He turned to face me. He enquired about the name of the journal. My reply pleased him because it was an accredited journal. A smile of satisfaction spread across his face and he said how pleased he was, and praised me generously. I was delighted! Until this incident, I had little idea about how deeply academic publications (and the authors thereof) were valued. This was a crucial moment and it motivated me to become an academic who taught meaningfully in undergraduate and postgraduate modules, who was a research supervisor, a published author, a principal investigator and participant in research projects. 


\section{Transforming teaching}

I begin this reflection on my pedagogy by looking back to my diary entry as a novice academic, sharing thoughts which arose on interrogating my teaching in the interregnum, and micro-movements which signaled changes in the trajectory of my practice.

My diary reflection in my first year as an academic provides telling clues to my identity as a novice academic.

\section{April 2008}

Taught nutrition. Showed clear, excellent quality pics of people suffering from kwashiorkor, anaemia, rickets and scurvy. Students felt revulsion at the scurvy one - bleeding gums! They paid attention. Someone asked about different kinds of anaemia- nice to know that they knew there was more than one kind. Am happy with notes - cover everything needed.

Looking inward, I realised I had become a traditional teacher and was promoting what Freire referred to as "banking education". I was making "deposits" by giving students copious bodies of notes and powerpoint slides, which they were expected to "patiently receive, memorise and repeat" (Freire, 1970, p.58). When I stated that the notes 'cover everything needed', I meant that the Incidence, Symptoms and Signs, Causes and Treatment/Management, and Prevention of each disease were included. And that was it. The end! My discourse was biomedical, based on centuries of Eurocentric science and scientists such as James Lind (scurvy), Daniel Whistler and Francis Glisson (rickets), and Cicely Williams (kwashiorkor). I was enacting this pedagogy within a socio-politically transforming South African context. This fledgling democracy enshrined grand aims and principles in its policies, such as the National Curriculum Statement for Life Sciences (Department of Education, 2011, pp.4-5), to guide teachers, and these included:

- Equipping learners, irrespective of their socio-economic background, race, gender, physical ability or intellectual ability, with the knowledge, skills and values necessary for self-fulfillment and meaningful participation in society as citizens of a free country 
- Social transformation: ensuring that the educational imbalances of the past are redressed

- Encouraging an active and critical approach to learning rather than rote and uncritical learning of truths

- Infusing the principles and practices of social and environmental justice and human rights as defined in the Constitution of the Republic of South Africa ... sensitive to issues of diversity such as poverty, inequality, race, gender, language. . .

- Valuing of indigenous knowledge systems

On reflection, I realised that my pedagogy was discordant with my deeply held beliefs and values about science education and its purpose, which resonated with the preceding aims and principles. My approach was flawed. Drawing from Fitzmaurice (2013) I see this critical moment as being underpinned by my obligation to students to teach for meaningful change. I realised I was not preparing science teachers to teach for 'social transformation', 'meaningful participation in society' and being 'sensitive to ... poverty, inequality. ..' as outlined in the policy. As a teacher educator in science, I needed to look outward towards ways which would heighten the awareness of pre-service science teachers, who were my students, about how they could transform their teaching and thereby transform their communities.

This change in my stance was not informed solely by education policy imperatives. I also aimed to craft a career which was moulded, in part, by the vision and mission of the tertiary institution which I served. I did so not simply to be compliant, but because these were underpinned by a liberatory ideology, which resonated with my personal views about the purpose of education. I sought to create spaces for my students and I to engage in critical forms of inquiry, to cultivate a spirit of social responsibility, and to promote self-sufficiency and empowerment in the wider society.

A focus on socially relevant science education by exploring socio-scientific issues became central to my pedagogy. I sought to model the role of a science teacher through my own teaching. I wanted to deviate from the scientistcentred approach to create a student-centred point of view, which focused on citizens as beneficiaries of science education. My goal was to motivate students to learn and teach science for "social responsibility" (Hayler, 2011, 
p.362). Later, through reading, it dawned on me that I had unwittingly adopted a humanistic perspective to science education (or perhaps the humanistic perspective had adopted me), which was somewhat subversive to traditional school science. Instead of values of submission and maintenance of the status quo, I decided to focus on values of transformation and emancipation, and to educate for critical consciousness. I wanted to navigate away from traditional science education with its 'top-down' approach, towards a liberating education, not merely for my students but with my students. According to Dos Santos (2009), a humanistic perspective to science education is underpinned by theoretical constructs from critical pedagogy and aims to transform oppressive contexts. Drawing on my experience as a school teacher, I was acutely mindful of the social chasm between working class and middle class learners (at schools) and students (at tertiary institutions). I wanted to raise my students' consciousness about how they could produce knowledge through human practices in order to address community challenges.

Borrowing from Freire (1976), the following guidelines for a transformative education applied to my practice:

1. Exploring students' socio-cultural contexts and concerns which could be applied to science education. I created the opportunity for dialogue and debate during the lecture periods, and students articulated many social challenges in their communities, including malnutrition and disease, poverty and environmental degradation. Based on students' views, instead of teaching about nutrition in the 'traditional' way as I had done previously, I developed a major project titled: Nutrition and health through food gardening. Students were required to work collaboratively with one another and other knowledge holders and develop strategies to promote self-sufficiency and resilience in their communities, by creating gardens for nutrition and alleviating health problems. Borrowing from Ferreira and Ebersohn (2012, p.32), I positioned the nutritional challenge as a "risk factor" and the student as the "protective resource". Instead of focusing on canonical science content embedded in the traditional scientific approach, my students engaged in a science which had practical utility and focused on social issues. 
2. Sharing the world with others. Students were required to work with community members, such as health care providers and teachers, to determine the prevalence and management of disease in the community.

3. Constructing and reconstructing the world. I engaged the services of a permaculturalist who taught students how to plant crops in a workshop activity (Figure 1). I also worked with an indigenous knowledge holder who taught students the value of African indigenous medicinal plants (Figure 2). I wanted to trouble the notion that "knowledge systems not rooted in the western mode of thinking are "naturally' subaltern" (Mudaly and Ismail, 2013, p.173). Through this project I sought to create a space for valuing and learning indigenous practices. In order to disrupt the idea that academics who were schooled in the western traditions of science, were the only source of legitimate knowledge, I engaged the services of custodians of indigenous knowledge and nonacademic experts in permaculture. The world of teaching and learning science within the teacher education milieu was reconstructed in these ways.

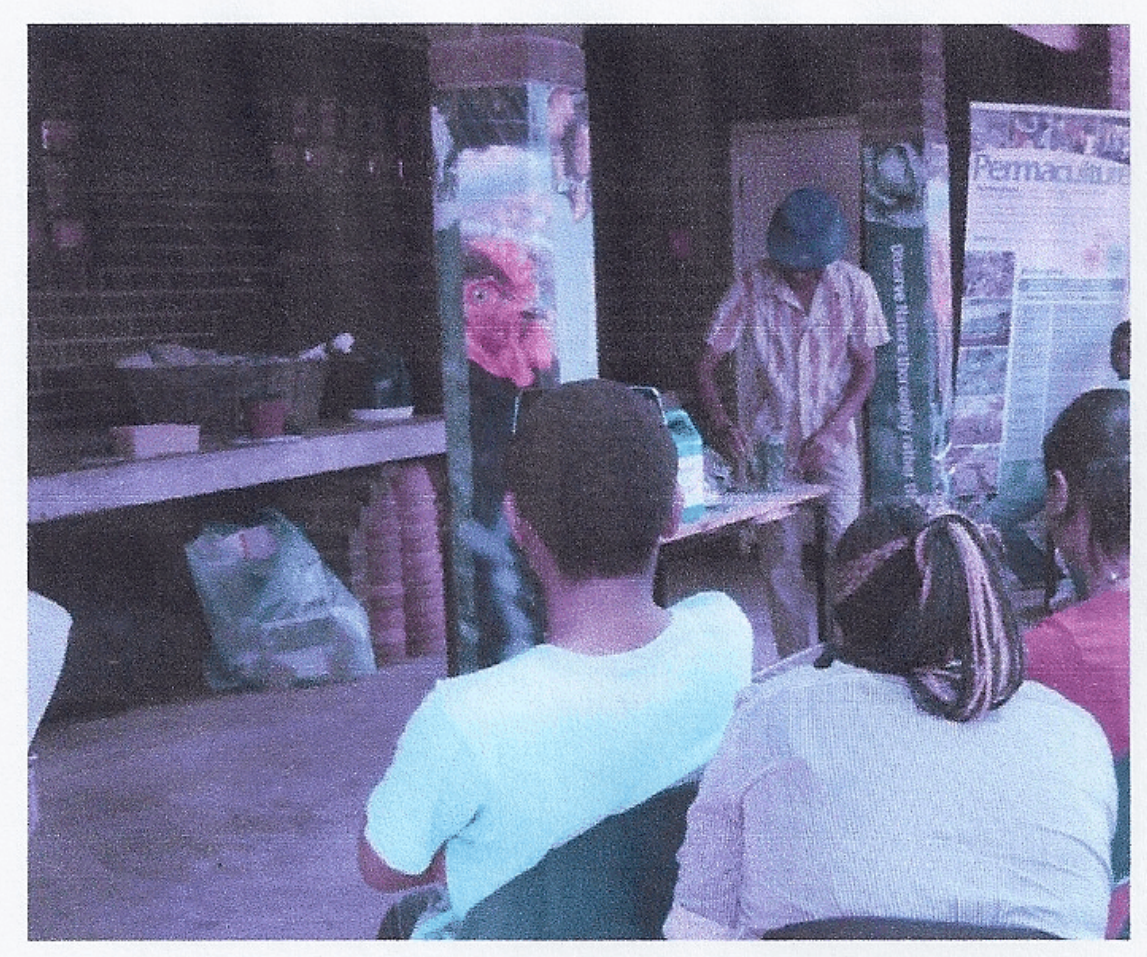

Figure 1: Permaculturalist as a teacher in higher education 


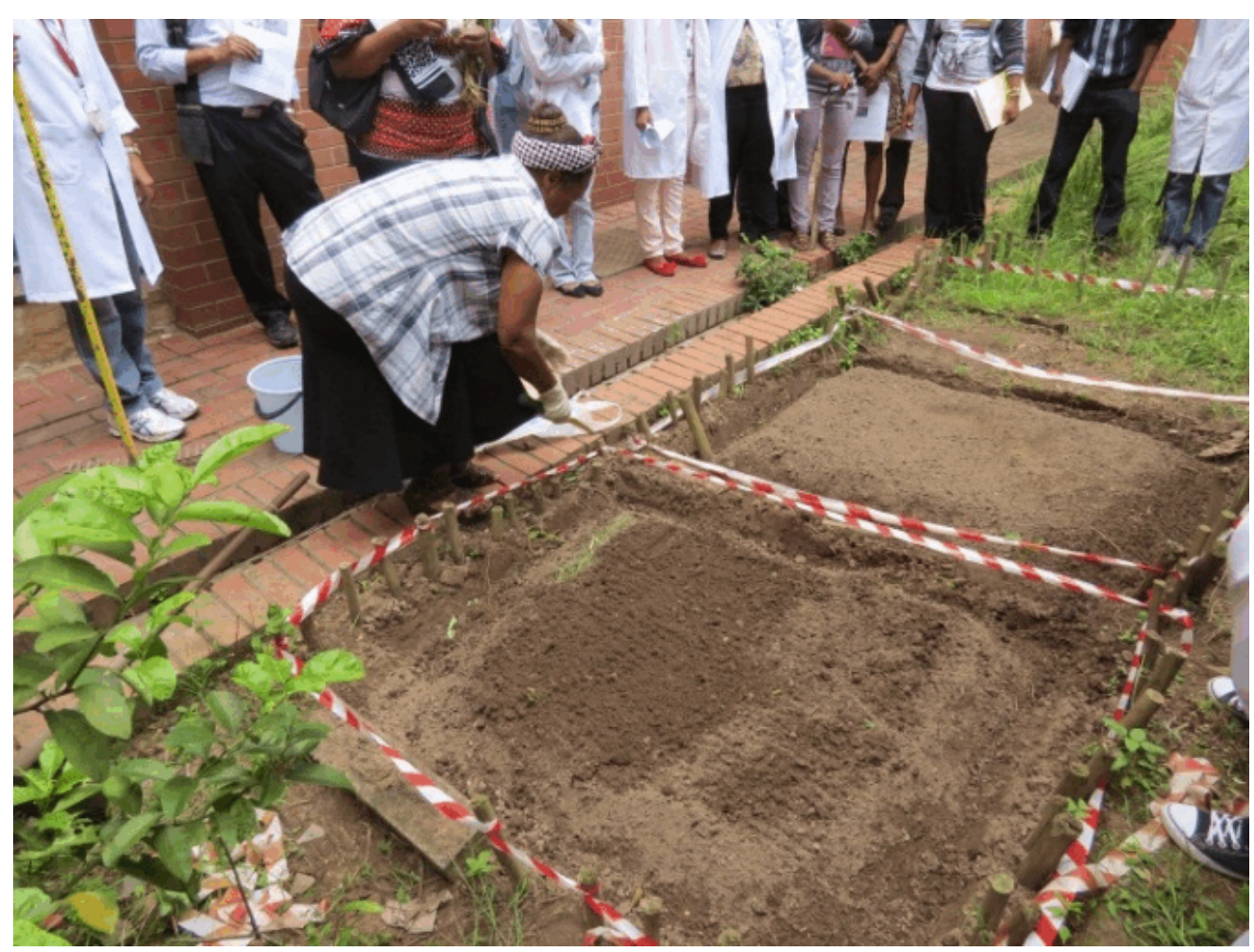

Figure 2: Traditional healer as a teacher in higher education

Students engaged in the transformation of the situation in their communities by developing food gardens on the university grounds and in selected schools. For me, multiple personal and professional goals, which were blurred because they overlapped, were met in and through this work. First, students learned how to cultivate gardens using permaculture methods and African indigenous methods, with a view to applying this knowledge when they became practicing teachers to address similar challenges in their school communities. Second, indigenous knowledge systems which had been marginalised for centuries were being restored and revalued in contemporary society. Third, the perpetuation of superordinate relations of power and knowledge, rooted in epistemic understandings of Euro-western education, was being disrupted. Fourth, students were being trained for community engagement using the vehicle of science education. Here, science education included sciences from different knowledge systems, which was taught by diverse knowledge holders. Finally, the traditional ways of learning to teach science were being disturbed through the pursuit of difference, which was navigated by collapsing disciplinary boundaries. Through this activity, students were enabled to "develop a critical comprehension of their social reality and transform it" (Dos Santos, 2009, p.374). 
The following excerpt from my teaching portfolio, developed in my sixth year of service, which expresses the rationale for my teaching approach, resonates with the pedagogy that I have described:

\section{January 2014}

I create a form of science education which encourages and enables students to reflect on their civic responsibility within the context of contemporary South African society. Educating students for critical consciousness by designing teaching and supervision in a way that words, pictures and actions generate a transformable praxis, influence my thinking. My teaching approach resonates with that of Paulo Freire (1994, p.78), who wrote in his book, Pedagogy of Hope: Reliving pedagogy of the oppressed:

. . let it not be said that, if I am a biology teacher, I must not go off into other considerations: - that I must only teach biology, as if the phenomenon of life could be understood apart from its historicalsocial, cultural and political framework. As if life, just life, could be lived in the same way ... in a favela (slum) ... as in the prosperous area of Sao Paulo's Gardens! If I am a biology teacher, obviously I must teach biology. But in doing so, I must not cut off from the framework of the whole.

By inserting science education into human reality, I teach more than physiology and anatomy in biology and science education; I transcend disciplinary boundaries by revealing how teachers can work with learners to co-construct knowledge and create spaces for a transformation of their identities.

This re-thinking of my practice occurred because I valued student-centred science education which ordinary people could apply in their daily lives. The following excerpt from my teaching portfolio sums up the theoretical considerations which underpinned the transformation of my practice as a higher education teacher:

\section{February 2015}

Drawing on theoretical insights from Aikenhead, Ogunniyi, Onwu, Kyle, Weiler, Giroux and Moletsane I show how teachers and learners can become agents of cultural production and not be passively locked in a process of cultural reproduction. 


\section{On becoming a researcher}

Three years after I had joined the university, I was invited to apply for a competitive grant for teaching and learning by a senior colleague who was familiar with my work in the science education department. It is possible that my identity as a higher education teacher in the undergraduate teaching modules, who used unconventional sources and methods, was what motivated my colleague to encourage me to design a research proposal, titled "Exploring learning and teaching methodologies in ethno-botany and integrating these in Life Sciences and Natural Sciences education Higher Education curricula". I was awarded the grant and served as the Principal Investigator, and worked in collaboration with two senior peers from the science education department. This signaled my move away from the periphery because for the first time, I felt that I belonged to a community characterised by "mutual engagement, joint enterprise and a shared repertoire" (Wenger, 1998, p.73). I had entered the community of practice for research. This was preceded by a change in spatial arrangements. Although I still occupied the post as a lecturer, I was moved into a large office, which was designed for use by a professor in terms of its furniture, equipment and lighting. I was thrilled and felt that this environment was conducive to my professional development.

\section{Entering and navigating the postgraduate teaching terrain}

I continued to feel excluded from postgraduate teaching in the science education department. Postgraduate modules were taught by senior academics in the Science Education Department and there was no space for me in that place. Borrowing from Walker (1998), I remained an outsider in that sacred postgraduate space for years. I felt that I was deemed as too inexperienced to traverse the postgraduate terrain. I was reminded of Chrisler's (1998) studies of higher education institutions which revealed men's roles as those of scholars, while women's roles were limited to teaching. The subtle barriers to women's advancement as scholars in higher education has been welldocumented (Mama, 2006; Tsikata, 2007; Walker, 1998). Novice academics in Dison's study (2004) also experienced marginalisation from scholarly work which was the domain of 'authentic', experienced, white researchers. It is possible that race, gender and experience, as "technologies of power" (Maritz and Prinsloo, 2015, p.696), were intersecting forces which made me believe 
that becoming an authentic female academic was impossible. I yearned to be more than a teacher; I aspired to become a scholar in science education. My view was that teaching postgraduate modules would give me the critical edge which would enable me to become a published author of academic work. In order to transcend this barrier, I realised that I had to engage in activities which required "sustained engagement and readjustment" (Wenger, 1998, p.53) to participate in the postgraduate sector. I requested a formal meeting with the Dean of Research in the Faculty of Education where I indicated the areas of my research interests, and my motivation to work in the postgraduate sector. Subsequently, I was invited to serve on committees to examine research proposals which were presented by Masters and $\mathrm{PhD}$ students. There was neither formal training for this work nor any remuneration in the form of workload hours or financial benefit. I read research proposals, and researched theoretical and analytic frameworks, to prepare to participate and "contribute to the negotiation of meaning by being a member of a community" (Wenger, 1998, p.55). The following diary entry in the second year of my work as an academic takes me backwards to that experience:

20 October 2009

I reviewed the $\mathrm{PhD}$ proposal about pregnancy among school going learners. I told the student that he was demonizing pregnant school girls. Was that (demonising) a harsh word? Maybe I should have said that he was victimizing the girls by positioning them as being 'bad'.

I feel I had used 'strong language' in order to impress the panel. That was not who I was, and I felt like a fraud for having used what I perceived to have been 'harsh language'. This inauthentic behaviour (Lechuga, 2012) on my part evoked feelings of guilt and remorse. In retrospect, it now becomes clear to me that I had been a novice academic and was doing all that I could to belong, and was desperately attempting to prove my epistemic credibility. It is possible that I did impress, because subsequently, I was invited to numerous proposal presentations. I was more careful about my choice of words and quickly learned the value of constructive critique. I tried to establish a 'safe space' in which students and supervisors could respond without feeling intimidated or humiliated, and I felt a greater sense of peace after such engagement. This deliberate choice to change my approach towards proposal defences emerged after personal reflection, and could signal an example of "emotional work" (Lechuga, 2012, p.88) in my academic development. 
Participation in examination panels marked my entry into the postgraduate community of practice, although this was not located within the science education discipline. I had achieved this by volunteering my time and effort to support students in their preparation for research, by serving as a member of research proposal examination panels. I was involved in "doing, talking, thinking, feeling and belonging" (Wenger, 1998, p.56), and in the fifth year of my work, I was requested to serve as chairperson of the panel. The following excerpt from my diary illuminates that experience:

\begin{abstract}
5 March 2013
I chaired the proposal panel today. There was little time to prepare- (the administrator) gave me a checklist of things to do. I started by welcoming members of the panel and the student. I told the student that he should not perceive this as a 'defence' but that it was a discussion to enable us to see that he had a realistic plan to conduct the research. I said that he needed to assure us that he was capable of doing research and that the panel intended to be supportive of his work. After the student and supervisor left the room, Dr S (a fellow panel member) remarked that this was the first time she had attended a proposal which was framed as a discussion, and where the student and supervisor were not made to feel as though they were on trial.
\end{abstract}

I became increasingly conscious that I could maintain the professional standards of the postgraduate community of practice without creating a cold, severely harsh and critical environment. My continued engagement in this community of practice reveals the "transformative potential" (Wenger, 1998, p.56) of participation. This participation was not limited to my "engagement in practice" (Wenger, 1998, p.57) but has contributed to part of who I have become. On 18 March 2014, based on the recommendation of a senior management member, I was appointed to serve on the College Research Committee. What began as voluntary participation in postgraduate panels in the School of Education evolved into a trajectory which "spanned boundaries" and linked communities of practice (Wenger, 1998, p.154). My participation spanned both the School and College communities.

My aspiration to teach on postgraduate modules persisted. Although I was a member of the community of practice of science teacher education, my participation remained peripheral because I was not involved in postgraduate teaching. The priority to graduate more Masters and Doctoral students became more urgent with each passing year to meet financial demands of the higher 
education institution. It is crucial for academics to lecture in postgraduate programmes in order to remain relevant and meet the needs which emerge from the "business-like management of higher education institutions" (Van Laren and Mudaly, 2012, p.1081).

After one proposal panel discussion, in my third year of higher education teaching, I was invited by a professor to teach on a generic module in the Masters programme, which was not located in the science discipline. As an undergraduate science teacher educator, I had built my identity on an interdisciplinary base, where I had merged disciplinary knowledge and knowledge from alternative systems. The generic Masters module had little in common with my work with undergraduate students, and I required professional support in order to develop as a postgraduate lecturer. I had to become what LaBoskey (2004a) refers to as both actor and spectator, and chose to engage with a "boundary trajectory identity" (Jawitz, 2009, p.248) in order to sustain my identity across the undergraduate and postgraduate communities of practice. As a novice academic in the postgraduate terrain, I had to gain access to this postgraduate teaching community and to contribute to it in a way that would make it part of my identity.

Teaching on post-graduate modules is valued because it plays a role in generating income through postgraduate output. I worked collaboratively with three senior academics to teach Masters students about designing research proposals. We were a diverse group of professionals from different disciplinary backgrounds. However, we "shared a passion for development of professional and social leadership" (Van Laren and Mudaly, 2012, p.1085) and this created the opportunity for mutual engagement, which connected us as academics. The following diary excerpt illuminates an experience of teaching on this module:

\section{March 2010}

I am exhausted. I have been ill and had a large number of scripts for MEd Assessment 3 to mark. Students' results seemed to have improved in the data collection plan assignment compared to literature review assignment. There was one piece which was a theoretical study and, on reading it, quite difficult to interpret. I asked (my colleague) to assess it for me. The student obtained $50 \%$ and was upset and left the lecture at tea time, and did not return for the rest of the day. The lecturer who helped me mark the script appeared concerned. I felt disappointed about the student not being able to cope with criticism and to learn from it. 
I was exhausted because the preparation to teach and assess students' work was intensive. I had to read and perform desktop studies in order to familiarise myself with the diverse research areas in which students were engaged. However, working with a team of academics in this postgraduate teaching community enabled me to feel that I was in a safe space to request assistance from my more experienced colleague whose areas of specialisation were conceptual and theoretical frameworks. My venturing into this unfamiliar territory was shaped by my own efforts and the efforts of my colleagues. Throughout our practice, we maintained a collegial arrangement which was enriched by "reciprocal peer learning" (Mudaly, 2012, p.47). The informal commitment of senior, more experienced academics to my professional development through the celebration of my small successes enabled me to reimagine my academic identity as a confident teacher in the postgraduate landscape. I learned that postgraduate students were diverse in terms of age, experience, language and writing proficiency, and personal life responsibilities and challenges, as compared to undergraduate students. I paid increasing attention to Hyatt's (2005) assertions about the deleterious effects of ill-conceived remarks made by academics, and I attempted to be more cautious and sensitive when I interacted with postgraduate students.

\section{From teacher to scholar}

My experience of teaching on the Masters module was invaluable. It paved the way for me to be entrusted with supervising research projects of postgraduate students within the science discipline. My postgraduate supervisory experiences were characterised by what Hugo (2009) describes as "complex and negotiated dialogical space between the supervisor and student". My identity as well as the identities of my students were moulded on socio-cultural histories, and involved creating spaces for networking with broader intellectual communities. My attachment to the emancipatory goals of education influenced the supervisory process. I underscored the importance of breathing life into abstract philosophical knowledge, by interweaving these with people's lived experiences, and developing feeling for people who live and are educated within a particular socio-historical context, with a view to using education as a vehicle for redressing power inequalities. During the last three years of my work, I graduated at least one postgraduate student per year. In 2014, one of my students was awarded her Masters degree summa cum laude. 


\section{Conclusion}

The features which characterise autoethnography (Ellis, Adams and Bochner, 2010) permeate this reconstruction of my academic self. I have offered detailed, evocative descriptions of interpersonal and personal experiences which shaped my professional identity during my academic journey. My methodological tools for reflexive inquiry enabled me to see and interpret the meaning of critical moments. In giving voice to my personal and cultural story, I disrupted the researcher/researched hierarchy by iteratively moving between and within both positions. Through this personal narrative, I "invite readers to enter the author's world and use what they learn there to reflect on, understand and cope with their own lives" (Ellis, 2004, p.46).

Interrogation of my micro-movements has illuminated spaces for selfimprovement. This occurred through a process of give and take, advocated by Wenger (1998), which involved my volunteering to serve the school in advancing its goals for postgraduate throughput. Through these activities, I became more visible and opportunities for interaction with other academics increased.

In this personal autobiographic account, I have consciously positioned myself as actor/practitioner and spectator/researcher and located my academic story as a subject of critical inquiry. I have provided insight into my multimembership which spanned several communities of practice, including communities of undergraduate teaching, postgraduate teaching, postgraduate supervision and collaborative discipline-specific research with peers. Using what Wenger refers to as "brokering", I selectively transferred elements from one practice to another (Wenger, 1998, p.109). In this "nexus of multimembership" (Wenger, 1998, p.159), the trajectories of my academic identities became part of one another. My academic identity shifted continuously, and transcended spatio-temporal boundaries, which embodied the past, present and future in "interlocked trajectories" (Wenger, 1998, p.158).

This work has implications for other academics, who feel that they are the over-worked servants of the knowledge class and trapped in the labour of teaching. It provides insights into transcending barriers associated with being perceived as an interdisciplinary researcher instead of a disciplinary expert, and discrimination which novice academics experience. This work illuminates 
ways in which fragmentation in academic life may be overcome. Ideas of brokering, joint enterprise, sharing of different skills and expertise through multimembership, can mobilise academics from the periphery towards the inside of the academic community, and fuel professional and personal inquiry, as well as transformation and renewal.

\section{References}

Archer, L. 2008. Younger academics' constructions of 'authenticity', 'success' and professional identity. Studies in Higher Education, 34(4): pp.385-403.

Ashley, L. and Peterson, R.N. 2015. A case for the use of autoethnography in nursing research. Journal of Advanced Nursing, 71(1): pp.226-233.

Bullough, R.V. and Pinnegar, S. 2001. Guidelines for quality in autobiographical forms of self-study research. Educational Researcher, 30(3): pp.13-21.

Canagarajah, A.S. 2012. Teacher development in a global profession: an autoethnography. Tesol Quarterly, 46(2): pp.258-279.

Chang, H. 2008 Autoethnography as method. Retrieved from http://www.academia.edu/1244871/Autoethnography as method on 25 September 2015.

Chrisler, J.C. 1998. Teacher versus scholar: role conflict for women? In Collins, H.L., Chrisler, J.C. and Quina, K. (Eds), Career strategies for women in Academe Arming Athena. London: Sage Publications.

Connelly, F.M. and Clandinin, D.J. 1990. Stories of experience and narrative inquiry. Educational Researcher, 19(5): pp.2-14. 
Delamont, S. 2007. Arguments against autoethnography. Paper presented at the British Educational Research Association Annual Conference: Institute of Education, University of London, 5-8 September 2007. Retrieved from http://www.cardiff.ac.uk/socsi/qualiti/QualitativeResearcher/QR_Issue4_Feb 07.pdf on 2 February 2015

Denzin, N. 2006. Analytic autoethnography, or Déjà vu all Over Again. Journal of Contemporary Ethnography, 35(4): pp.419-428.

Department of Education. 2011. Curriculum Assessment and Policy Statement Life Sciences. Pretoria: Government Printer.

Dison, A. 2004. "Finding her own academic self": research capacity development and identity formation. Perspectives in Education, 22(4): pp.83-98.

Dos Santos, W.L. P. 2009. Scientific literacy: a Freirean perspective as a radical view of humanistic science education. Science Education, 93: pp.361-382.

Ellis, C. 2004. The ethnographic I: a methodological novel about autoethnography. Walnut Creek, California: AltaMira Press.

Ellis, C. and Bochner, A.P. 2000. Autoethnography, personal narrative, reflexivity: researcher as subject. In Denzin, N.K. and Lincoln, Y.S. (Eds), Handbook of qualitative research (2nd ed.). Thousand Oaks, CA: Sage, pp.733-769.

Ellis, C., Adams, T.E. and Bochner, A.P. 2010. Autoethnography: an Overview. Retrieved from http://www.qualitative-research.net/index.php/fqs/article/view/1589/3095 on 2 May 2015.

Ferreira, R. and Ebersohn, L. 2012. Partnering for resilience. Braamfontein, South Africa: Van Schaik Publishers.

Fitzmaurice, M. 2013. Constructing professional identity as a new academic: a moral endeavour. Studies in Higher Education, 38(4): pp.613-622.

Freire, P. 1970. Pedagogy of the oppressed. New York: The Seabury Press. 
Freire, P. 1976. Education. The practice of freedom. London: Writers and Readers.

Freire, P. 1994. Pedagogy of hope: reliving pedagogy of the oppressed. New York: Continuum.

Greene, M. 1971. Curriculum as consciousness. Retrieved from http://www.udel.edu/educ/whitson/897s05/files/Curriculum\%20and\%20Cons ciousness.htm on 2 May 2015.

Hayler, M. 2011. Autoethnography, self-narrative and teacher education. United Kingdom: Sense Publishers.

Hugo, W. 2009. Spiraling reference: a case study of apprenticeship into an academic community of practice. South African Journal of Higher Education, 23(4): pp.703-721.

Husu, L. 2001. On metaphors of the position of women in academia and science. Nordic Journal of Feminist and Gender Research, 9(3): pp.172-181.

Hyatt, D.F. 2005. 'Yes, a very good point!': a critical genre analysis of a corpus of feedback commentaries on Master of Education assignments. Teaching in Higher Education, 10(3): pp.339-353.

Jawitz, J. 2009. Academic identities and communities of practice in a professional discipline. Teaching in Higher Education, 14(3): pp.241-251.

LaBoskey, V.L. 2004a. Representing self-study in research and practice: foreward to section three. In Loughran, J.J., Hamilton, M.L., LaBoskey, V.K. and Russell, T. (Eds), International handbook of self-study of teaching and teacher education practices. Dordrecht: Springer, pp.813-816.

LaBoskey, V.L. 2004b. The methodology of self-study and its theoretical underpinnings. In Loughran, J.J., Hamilton, M.L., LaBoskey, V.K. and Russell, T. (Eds), International handbook of self-study of teaching and teacher education practices. Dordrecht: Springer, pp.817-869.

Lechuga, V.M. 2012. Emotional management and motivation. New Directions for Institutional Research, 155: pp.85-98. 
Loughran, J.J. 2004. A history and context of self-study of teaching and teacher educator practices. In Loughran, J.J., Hamilton, M.L., LaBoskey, V.K. and Russell, T. (Eds), International handbook of self-study of teaching and teacher education practices. Dordrecht: Springer, pp.1-816.

Maistry, S. 2015. Accountability and surveillance: new mechanisms of control in higher education. Transformation, 88: pp.25-35.

Mama, A. 2006. Pursuing gender equality in the African university.

International Journal of African Renaissance Studies, 1(1): pp.53-79.

Maritz, J. and Prinsloo, P. 2015. 'Queering' and querying academic identities in postgraduate education. Higher Education Research and Development, 34(4): pp.695-708.

McAlpine, L., Amundsen, C. and Turner, G. 2014. Identity-trajectory: reframing early career academic experience. British Educational Research Journal, 40(6): pp.952-969.

Mudaly, R. 2012. Gazing inward: teaching in the postgraduate milieu. Alternation, 19(2): pp.38-56.

Mudaly, R. and Ismail, R. 2013. Teacher learning through tapping into indigenous knowledge systems in the science classroom. Alternation, 20(1): pp.178-202.

Pithouse, K., Mitchell, C. and Webb, S. 2009. Self-study in teaching and teacher development: a call to action. Educational Action Research, 17(1): pp.43-62.

Portnoi, L. 2009. Cultivating the next generation of academics in South Africa. Africa Education Review, 6(2): pp.187-207.

Spry, T. 2001. Performing autoethnography: an embodied methodological practice. Qualitative Inquiry, 7: pp.706-732.

Tsikata, D. 2007. Gender, institutional cultures and career trajectories of Faculty of the University of Ghana. Feminist Africa, 8: pp.26-41. 
Van Laren, L. and Mudaly, R. 2012. Navigating the postgraduate terrain through a community of practice: reflections of novice academics. South African Journal of Higher Education, 26(5): pp.1080-1094.

Walker, M. 1998. Academic identities: women on a South African landscape. British Journal of Sociology of Education, 19(3): pp.335-354.

Wenger, E. 1998. Communities of practice learning, meaning and identity. New York: Cambridge University Press.

Ronicka Mudaly

Science and Technology Education Cluster University of KwaZulu-Natal $\underline{\text { mudalyr@ukzn.ac.za }}$ 